\title{
Teaching Practice Patterns in ECE Teacher Program in Distance Education in Indonesia
}

\author{
Sri Tatminingsih ${ }^{\bowtie}$ \\ Pendidikan Guru Pendidikan Anak Usia Dini, Universitas Terbuka \\ DOI: $\underline{10.31004 / \text { obsesi.v5i1.599 }}$
}

\begin{abstract}
This purpose paper describes a pattern of micro teaching in teacher education through online learning programme using the moodle application. This article was the result of a study with qualitative paradigm. Research method with survey and data collecting using structured interviews and questionnaires. The research subjects were students who took online tutorial in Strengthening Teaching Courses (STC) in The Early Childhood Teacher Education in Universitas Terbuka (UT), Indonesia in 2018. The finding of the research are online micro teaching patterns in the Online STC that have similarities with face-to-face tutorials. Teaching practices should be a cycle: planning, implementation, evaluation and reflection on their own teaching practices. In addition, to evaluate themselves, students can also be evaluated by the others students and peers by online. In online tutorial, the pattern of micro teaching developed is simpler to understand by students independently and can be an alternative practice teaching course in online teacher education program.
\end{abstract}

Keywords: online learning; early childhood education; teaching practice.

\begin{abstract}
Abstrak
Artikel ini bertujuan mendeskripsikan pola praktek mengajar pada pendidikan guru melalui program pembelajaran online menggunakan aplikasi moodle. Artikel ini merupakan hasil kajian dengan paradigma deskriptif kualitatif. Penelitian dilakukan dengan metode survei. Pengumpulan data dilakukan melalui kuesioner dengan pertanyaan terbuka dan wawancara terstruktur. Subjek penelitian adalah mahasiswa Program Pendidikan Guru Pendidikan Anak Usia Dini (PGPAUD) Universitas Terbuka Indonesia yang mengikuti perkuliahan pada mata kuliah Pemantapan Kemampuan Mengajar (PKM) secara online pada tahun 2018. Temuan penelitian menunjukan bahwa pola praktik mengajar pada perkuliahan secara online memiliki kesamaan dengan pola praktik mengajar secara tatap muka. Praktik mengajar ini dilakukan melalui siklus yang terdiri dari merencanakan, menerapkan, mengevaluasi dan merefleksi yang dilakukan sendiri oleh mahasiswa. Setiap mahasiswa juga dapat mengevaluasi praktik yang dilakukannya melalui evalusi dari mahasiswa lain dan teman sejawatnya secara online. Pola praktik mengajar ini dikembangkan dalam bentuk yang sederhana agar mudah dipahami oleh mahasiswa dan pola ini dapat menjadi alternatif mata kuliah praktik mengajar pada program pendidikan guru.

Kata kunci: pembelajaran online; pendidikan anak usia dini; praktik mengajar.
\end{abstract}

Copyright (c) 2020 Sri Tatminingsih

$\triangle$ Corresponding author:

Email Address : tatmi@ecampus.ut.ac.id (Jl Cabe Raya- Pamulang-Tangerang Selatan)

Received 11 June 2020, Accepted 16 August 2020, Published 5 September 2020 


\section{INTRODUCTION}

Online learning systems are currently growing rapidly and are increasingly in demand by many universities in the world (Sokolova, et.al., 2018). This learning system accommodates many people's learning needs that are constrained by distance and time (Traxler, 2018) and facilitates teachers to improve their competencies (Nguyen, 2017). Similarly, education for Early Childhood Education (ECE) teachers. The use of Information and Communication Technology (ICT), especially internet-based ones, has actually become a necessity in education. Especially in the teacher education program. Aside from being a means to teach, ICT is also very much needed in learning for those who take part in teacher education programs (Nikolopoulou, 2015). Actually, this online system is very suitable for Indonesia, which has a large geographical area and 13,675 islands and spreads from $6^{\circ} \mathrm{N}-11^{\circ}$ South Latitude and $95^{\circ}-141^{\circ}$ East Longitude (Hal Hill, et.al., 2014) because of the vastness of the area, it also causes the spread to be uneven, including in the education sector. In addition, the Indonesian people are also not familiar with distance education or online learning (Diki, 2013). However, Indonesia Open University, Universitas Terbuka (UT) which organizes distance education, tries to develop online learning for all its study programs.

A teacher not only has a formal academic requirement in the form of a diploma or certificate, but he must also be competent and have good teaching skills and can follow the development of science and be able to change with the changing times (Zakiya and Nurhafizah, 2019). ECE teachers must have an understanding of the curriculum applicable to early childhood, but there are still many of those in the category who are only able to interpret its meaningfulness to the point of modeling it in its learning (Rohita, 2018). One of the main competencies that must be possessed by an ECE teacher is the ability to teach (Michalopoulou, 2017). In addition to the ability to teach, ECE teachers must also have educational skills. These include skills, knowledge, attitudes, habits, communication, cognitive skills, intellectual abilities, wisdom, ingenuity, truth, honesty and creativity (Currie, 2020). The ability to teach and educate must be trained intensively. In the teacher education curriculum, there is usually some overlapping material. This is very reasonable because usually teacher education providers want to provide a lot of material to their students. This also happened in Turkey ( $\mathrm{T}$. Atay, et.al, 2018), in Turkey's previous curriculum, there were some courses with overlapping content. At the beginning, these courses were designed to deliver the subject matter in more than one semester; yet, it did not work as intended during the implementation period. One example is when the teacher must implement a comprehensive learning model to improve children's social-emotional abilities, the teacher must have good teaching skills, such as the ability to explain material, the ability to ask questions, evaluation skills, ability to observe and soothing abilities. These skills are needed in applying the learning model and cannot be replaced by any media (Tatminingsih, 2019). Basma Faour stated that young children will be more confident and comfortable when they are taught by teachers who have good readiness and teaching skills acquired through adequate teacher education. Lack of teacher competence in teaching will cause children to be uncomfortable (Faour, 2003).

The experience of teaching practice or micro teaching is very important in the teacher education program. This experience is one of the mandatory curricula. This is in line with the opinion of (Undiyaundeye, 2018) which states that micro-teaching is one of the most recent innovations in teacher education programs which aims at modifying teachers' behavior according to modified objects. Education in the country has been recognized as important for micro-teaching in preparing classroom teachers. Micro-teaching is one of those innovative ideas that have been used, in recent years, to improve classroom teaching. The impact of practice learning experiences on the views of prospective teachers in the ECE pre-service education program. It mainly focuses on multiple concepts that emerge as a result of minilessons executing in colleagues in simulated situations. Micro-teaching helps the teacher to overcome problems related to getting ready for class and presenting the lesson (Billen, 2015). Micro-teaching is based on social learning theory (Bandura, 1982). Demirel states that 
micro teaching was first developed at Stanford University in 1960 as part of an experimental program that aimed to increase quality in teacher training (Billen, 2015). Rebecca Hun Ping Cheung stated that there are four main domains in teacher teaching practices, namely the characteristics of teachers, the learning environment, the teaching strategies, the criteria for used to judge children's creativity (Cheung, 2012; Yildirim, 2010). The four domains will show that teachers who have attended teaching practice courses will be able to educate and teach according to expectations.

Meanwhile, (Higgins, 2004) stated that teaching practice is a cycle. The meaning is that teaching practices carried out by teacher education students must carry out repetitive layered teaching practices. They must practice making plans for teaching, teaching, reflecting and redrafting plans with improvements from previous practices. They must practice making plans for teaching, teaching, reflecting and re-drafting plans with improvements from previous practices. The same is done in the Teaching Strengthening Capabilities course of UT's ECE Teacher Education. students must practice teaching eight times where the second practice is an improvement from the first practice, and the third practice is an improvement from the second practice and so on. Repairs carried out by students must be based on reflections taken by themselves and/or obtained from supervisors' input. This is, as stated by (Kazu, 1996), namely: one of the most important links of the micro teaching process is the re-teaching process that will be developed through the thinking style and potential provided to student at the start and end of the teaching experiment and the feedback provided.

Teaching practice courses or Strengthening Teaching Capabilities (STC) course in the UT's ECE Teacher Education Study Program has just held an online tutorial for the 2018 on semester July-December. Previously this subject was included in a face-to-face tutorial. The ECE Teacher Education Study Program has been held since 2007. Therefore, the learning pattern of this course still uses face-to-face tutorials. The STC course is a course that requires students to practice with repetitive layered systems where students make improvements to learning independently. Improvement of this learning is done by doing lesson study. Lesson Study (LS) is an approach to improving learning. LS provide a process for collaborating and designing lessons and evaluating the success of teaching strategies that have been applied in an effort to improve the process and acquisition of student learning (Lewis, 2002). In the LS process, the teacher works together to plan, teach, and observe the learning that he develops cooperatively. Meanwhile, a teacher implements learning in the classroom, others observe, and record questions and understanding of students (Suhartono, 2015). Therefore, this study aims to find a pattern of teaching practice in ECE teacher education in education with a distance learning system. Novak (1998) states that learning requires the use of technology that can integrate the learning process itself (Keengwe, 2009). This technology is used as a tool to actively support teaching and learning tasks so students learn to build their own knowledge through the completion of creative activities that enhance meaningful learning (Keengwe, 2009). This is what is applied in implementing TSC courses online. The use of ICT in this teaching practice course should not make this subject difficult and complicated, but instead must make this course an easy and comfortable learning. The main point is the achievement of key competencies, both as ECE teachers and elementary school teachers (Palomino, 2016).

Therefore, this paper describes the results of research that discuss the pattern of online tutorials in teaching practice courses in ECE teacher education programs in distance education in Indonesia. The organization of this paper is as follows. Section two recalls the theoretical background and methodology. Section three shows the results of research and discussion. In Section four, we discuss about the model of online tutorial patterns. At the end, this article will be closed with a conclusion in Section five.

\section{Teaching Practise and Online Learning}

Teaching practices must be given in teacher training for several reasons, namely: 1) Each teacher comes from a different background so it is necessary to train the standard of the 
process in teaching; 2) In teaching practice, teachers are trained to bring up all their competencies in managing classes and curriculum; 3 ) In teaching practice, teachers are given the opportunity to be able to provide the best service to their students, 4) teaching practices must be guided intensively by mentors who are experienced and have knowledge of learning and teaching; 5) in teaching practice, teachers can broaden their insights and in depth about early childhood development knowledge and material (Gasbarro, 2008).

Fahrman, et. al., stated that the teaching practice carried out by the teacher before he actually became a teacher played a very important role in the learning process in children. In order for the learning process to succeed, the teacher must have sufficient knowledge and experience in several different fields (Fahrman, et. al., 2020). Fatmasari and Suripto stated that teaching practice is an activity designed to enable teachers to have expertise in teaching in front of the class so that the teacher can test his ability to apply the theories and knowledge he gets while studying in a teacher education institution (Fatmasari, 2018). In distance education, the use of the internet is important in implementing teaching practice courses, for example by using The World Wide Web, or 'Web' for short. With the web, teaching practice activities can be carried out in two directions even though the lecturers and students are in a distance (Polovina, 2014).

\section{The Teaching Practice Patterns in Online TSC course on ECE Teacher Education Program}

In this section, we will discuss teaching practice patterns in online TSC at the Universitas Terbuka and the results of data analysis that has been carried out regarding this teaching practice.

The TSC is a practice course that requires students to practice teaching throughout the lecture period. Students are asked to practice at the school where they teach. When carrying out this practice, students are assessed by supervisors who were previously chosen by students themselves.

Teaching practice is a practical subject contained in the ECE teacher education curriculum in all universities that open this program even though the name of the course in each college is not the same. This course requires students to teaching practice as long as students follow this course. It usually lasts for one semester. In the TSC course in UT, students are asked to practice at the school where they teach. When carrying out this practice, students are assessed by supervisors who were previously chosen by students themselves. According to the TSC handbook (FKIP Team, 2017). The TSC is the final estuary of the program that trains and equips students with the ability to organize (prepare, design, implement, evaluate and improve) early childhood learning based on scientific principles of early childhood education. The Teaching Practice Patterns in TSC course by face to face tutorial is generally described as Fig. 1 (FKIP Team, 2017).

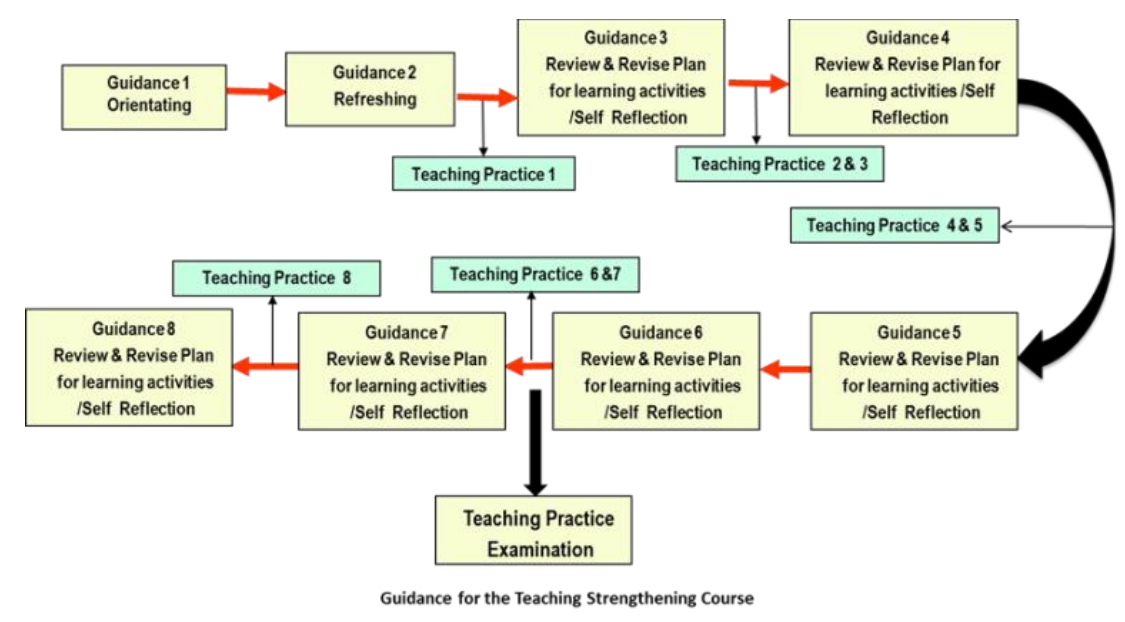

Fig. 1 The Teaching Practice Patterns in TSC course by Face to Face Tutorial 
The pattern illustrates that the tutorial activities in the TSC course consist of eight meetings held every Sunday, where students meet with tutors who guide them in the course. The number of practices that must be done by students as much as 8 times is done on weekdays between the time of face-to-face tutorial This teaching practice is carried out in the classroom where students teach in kindergarten or play groups. The pattern also shows what students activities take in each tutorial, including arranging, revising the learning plan that will be used for practice, making the results of self-reflection. Practices carried out by students are monitored and assessed by the Supervisor chosen by the students themselves at the beginning of joining this course. Assessment is carried out on the planning and implementation of teaching practices. In this pattern also appears, the number of practices that must be done by students during the tutorial takes place, namely eight times teaching practice. Every time you have finished teaching practice, students must make a report in the form of a reflection sheet. But in this pattern it is not clearly illustrated for the practice of teaching which reflection sheet he made. Practical exam activities are carried out in kindergarten/ playgroup which are determined by the regional office and are usually located around the student's place so that students do not find it difficult to reach the practice exam place. At the end of the coaching, students must collect practice reports containing lesson plan and self-reflection sheets that they make during teaching practice.

\section{METHODOLOGY}

This study applies Paradigm research with survey methods and using structured interviews and questionnaires. This method is used in order to be able to dig deeply into the practical courses conducted online. The research subjects are 2 online learning classes in Teaching Ability Stabilization courses in the 2018.2 semester or odd semester which take place September - December 2018. Each class consists of 10 students, so the total respondents are 20 students. However, of the 20 students only 15 students were active in the Online Tutorial (OT) and all were used as research respondents.

The process of data collection is done in an integrated manner in online tutorial class activities. The stages are: 1 ) the questionnaire is delivered in the OT class in a discussion forum and students are asked to answer it. 2) Student answers are entered and grouped according to the similarity of the answers. 3) Based on the results of grouping, the unique data is then deepened by asking questions to students individually (by email). 4) Data is then analyzed and described as the results of research through triangulation.

Data is collected using questionnaires uploaded into the online tutorial application. This questionnaire contains five open questions, as follows in table 1.

Table 1 Content of questionnaire

\begin{tabular}{|c|c|c|}
\hline No & Data sought & Question \\
\hline 1. & $\begin{array}{l}\text { The reason students take } \\
\text { online tutorials on STC courses }\end{array}$ & $\begin{array}{l}\text { Why did you choose an online tutorial on this } \\
\text { course? }\end{array}$ \\
\hline 2. & $\begin{array}{l}\text { Constraints and convenience } \\
\text { of attending OT in online TSC } \\
\text { course }\end{array}$ & $\begin{array}{l}\text { What Constraints and convenience of } \\
\text { attending OT in online TSC course? }\end{array}$ \\
\hline 3. & $\begin{array}{l}\text { Feedback about The Teaching } \\
\text { Practice Patterns (Figure 1) }\end{array}$ & $\begin{array}{l}\text { How do you respond about The Teaching Practice } \\
\text { Patterns in TSC course? Your answers may be more } \\
\text { than one. }\end{array}$ \\
\hline 4. & $\begin{array}{l}\text { Effective teaching practice } \\
\text { patterns in online TSC course }\end{array}$ & $\begin{array}{l}\text { What is the pattern of online TSC course that you } \\
\text { think is effective? Your answers may be more than } \\
\text { one. }\end{array}$ \\
\hline 5. & $\begin{array}{l}\text { Components of The Teaching } \\
\text { Practice Patterns in TSC course }\end{array}$ & $\begin{array}{l}\text { What components need to be added to The Teaching } \\
\text { Practice Patterns in TSC course and what are the } \\
\text { reasons? }\end{array}$ \\
\hline
\end{tabular}




\section{Overview of Research Subject}

The number of research subjects was 20 students who participated in the TSC online in the 2018.2 semester (July-December). They come from two different classes because one TSC Course class consists of 10-15 students. A total of six subjects were in the age range of 25-35 years and nine subjects were in the age range of 35-45 years. All research subjects teach in kindergarten with work experience of between 5 - 25 years. The subjects are three in Mataram, six in Palangkaraya, four in Padang and two in Bandung. Student who take the online TSC course are students who are in the fifth and sixth semesters. This course should be taken through face-to-face tutorials by students in the fourth semester. However, in the semester package this student encountered problems so they had to repeat it in the next semester. Because there were no face-to-face classes in semester 2018.2 they had to take online tutorials.

\section{RESULT AND DISSCUSSION}

\section{Reasons for joining online TSC course}

These answers are then summarized into three categories as follows; 1) The first reason is because in the area where they enrolled in this course, the quota was not reached to form one face-to-face tutorial class where one TSC course tutorial class had to fulfill a quota of 1015 students. Therefore, they were forced to take an online tutorial for this course. The number of respondents who gave this reason was seven people, 2) The second reason is that from the start, they did choose to take this online course because they realize that they do not have time to attend face-to-face tutorials on Saturday or Sunday, including: they must work ship; they have family events; they have other activities. the research subject who gave this second reason as many as five people, 3) The third reason is answered by three people. They point out this reason, because the cost of online tutorials is much cheaper and the time is more flexible than face-to-face tutorials. They don't need transport costs and can do it from home or school. They can do tutorials or coaching at any time according to their time and do not depend on others.

Based on aforementioned above, it appears that the top two answers are reasons caused by unintentional conditions by students. They were forced to follow OT because they could not attend face-to-face tutorial classes. Meanwhile, the subjects who did intentionally follow OT were those who realized that the costs, time and benefits were greater than taking face-to-face tutorials. So overall, the online tutorial for this online TSC course is not an option that is deliberately chosen by students. Basically, they want face-to-face tutorials. however, the choice of subjects following online learning is in line with the statement of Indira Dhull and MS. Sakshi, namely: 1) Online learning provides accessibility so that students can learn from anywhere in the world. This is a very important consideration for students who want to study but are constrained by distance so that students' learning options are not limited by their geographic locations. Thus the learning process can be followed from home. 2) The Online Learning System allows students to define and process learning styles, content, goals, current knowledge and individual skills. Therefore, in this online learning, students can determine their own learning process according to themselves. 3) Online learning also helps students expand access to the outside world and helps them develop their ICT skills (Dhull and Sakshi, 2017). Another reason contained in the subject statement is the desire from within itself to take part in online learning. This is in line with the opinion of Anfas et al., that in distance education, internal factors greatly determine learning achievement college student. Especially motivation in learning, because in the distance learning system, student independenceis very much required during the learning process (Anfas, et.al., 2020; Cho, M.H., \& Heron, M. L., 2015) 


\section{Constraints and convenience of attending OT in TSC course}

All these subjects provide answers that vary from one answer to the most four answers. The results obtained are then sorted according to the number of subjects who answered them.

\section{Table 1 Constraints and convenience felt by students}

\begin{tabular}{|c|c|c|}
\hline & The Constraints & The conveniences \\
\hline b. & $\begin{array}{l}\text { Unstable internet network. This greatly } \\
\text { inhibits students from being able to } \\
\text { access OT on time and high cost for internet } \\
\text { data package } \\
\text { Unable to upload assignments on time } \\
\text { because they do not have time to open } \\
\text { the OT application. }\end{array}$ & $\begin{array}{l}\text { a. The time is very flexible to open OT class, it can } \\
\text { be in the morning or evening and does not } \\
\text { interfere with work time. } \\
\text { b. Can be done anywhere as long as there is an } \\
\text { internet connection. } \\
\text { c. OT stages and schedules are very clear so that } \\
\text { they can be followed easily. }\end{array}$ \\
\hline $\begin{array}{l}\text { c. } \\
\text { d. } \\
\text { e. }\end{array}$ & $\begin{array}{l}\text { Do not have a place to ask directly. } \\
\text { Not familiar with online learning, } \\
\text { It is not easy to understand the contents of } \\
\text { the material or assignments which are only } \\
\text { described in writing. }\end{array}$ & $\begin{array}{l}\text { d. Practical tasks are easy to implement which are } \\
\text { important for students to be diligent and } \\
\text { honest when doing their practice. } \\
\text { e. Practice in your own school so that it does not } \\
\text { interfere with teaching time. }\end{array}$ \\
\hline g. & $\begin{array}{l}\text { Difficult to divide time for teaching practice } \\
\text { activities and activities as daily teachers as } \\
\text { kindergarten teachers, because the tasks } \\
\text { in OT are very dense and must be done } \\
\text { alone. } \\
\text { It is difficult to ask Supervisors to provide } \\
\text { an assessment in the implementation of } \\
\text { teaching practices. }\end{array}$ & $\begin{array}{l}\text { f. OT tutors are very accommodating } \\
\text { and responsive, especially in discussion } \\
\text { forums when students have difficulty } \\
\text { understanding the material in OT. } \\
\text { g. All tasks can be collected (uploaded) to the } \\
\text { application quickly, provided the internet } \\
\text { connection is smooth. This can be done, } \\
\text { especially at night. }\end{array}$ \\
\hline
\end{tabular}

The constraints and convenience in following the teaching practice in this online TSC course which are presented in table 2 are basically not much different from the result of the Dhull and Sakshi studies. They opinion about convenience includes accessibility in terms of time and place, individual learning, easy to implement and follow. Meanwhile, the obstacles include not all students having good ICT skills, not getting immediate responses, poor communication, and feeling isolated (Dhull and Sakshi, 2017). One thing that was interesting, the subject stated that online teaching practice was high cost, Dhull and Sakshi actually stated that it was low cost. This difference is very possible considering that in Indonesia the internet signal is not evenly distributed due to the very varied demographic location.

Another thing that is interesting is related to ICT and e-literation skills. Subjects argued that they had difficult following this course because their skills in ICT and e-literation were still insufficient. Whereas based on results of Meita Istianda's research that through online learning students can improve their ICT and e-literation skills (Istianda, 2019). In addition, She argues that online learning can increase the level of student's interaction with learning materials and learning components such: other students and tutors (Istianda, 2019). This is different from the opinion of subjects who feel isolated and have difficulty interacting with others. This difference is very reasonable because these opinion are based on different perceptions. Istianda's opinion is viewed from the online learning management side and the subject's opinion is viewed from the online learning user side.

\section{The subject's response to the existing teaching practice patterns in online TSC course}

The teaching practice patterns in online TSC course as can be seen in Fig. 1 The results of the analysis are summarized into four answers, as follows; 1 ) This pattern is very good and can be easily followed by students. The pattern is also the same as the pattern contained in the guide and can accommodate the expected competencies of the TSC course. With this pattern, students can carry out teaching practices optimally and can improve their teaching strategies independently, 2) This pattern is somewhat confusing because the pattern, it is illustrated that 
there are activities that must be carried out outside the meeting. On face-to-face activities this takes place on weekdays or Mondays to Saturdays and meetings are held on Sundays. In the OT class there are no days outside initiation because the initiation lasts for seven full days, 3) This pattern does not match the online tutorial. Even though the pattern is contained in the TSC course handbook, it is intended for face-to-face tutorials so that students cannot follow the pattern properly. In addition, the assignments are also unclear and students have difficulty asking, because the explanation given by OT tutors is in the form of writing with limited sentences, 4) A small number of students (only one person) stated that he did not care about the pattern. He just followed what was there and he did experience problems when uploading some of the results of the practice files, but with the help of others, he still managed to upload them and OT which he did smoothly.

The pattern of teaching practice in online TSC course seems to have tried to accommodate the ability of teachers to plan, implement learning, evaluate and reflect on their teaching abilities. This is in line with the opinion (Kusmawan, 2017) which states that teaching practice or micro teaching should be a forum that facilitates critical reflection, allowing teachers to explore various possible perspectives while building opportunities to compare and contrast these perspectives and make specific elements stand out more. What they already have. The opinion of the subject stating that this pattern has accommodated them to take part in the learning process with intensive interaction between students and tutors and paying attention to the characteristics of students who are participating in this program is in line with the statement (McMillion, and King, 2017)

\section{Effective teaching practice patterns in online TSC Course}

All subjects answered this question unfortunately they did not give the specific ones. Nevertheless, we tried to analyze them by deepening the student's answers via email personally to the student. The grouping of answers is categorized into the main answer, starting with a positive answer. Student answer analysis is divided into two main components that the general answer and the answers after being deepened and asked for more specifically. Student answers are sorted by their urgency. The answer is illustrated in following Table 3.

Table 3 Effective Teaching Practice Patterns in Online TSC Course

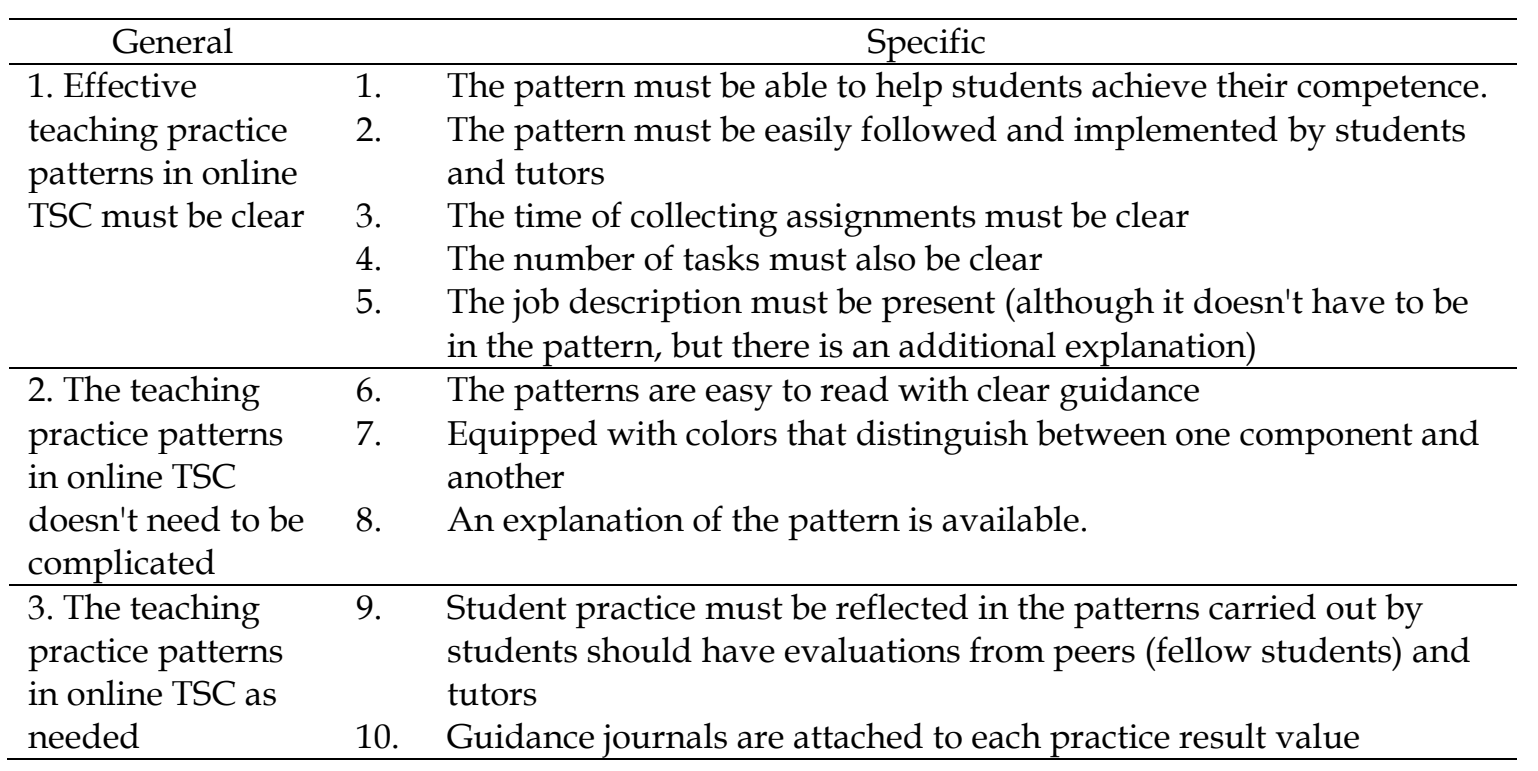

Basically, the pattern of effective teaching practice according to the research subjects is the process of teaching practice or micro teaching based on social learning theory, which fulfills educational interaction, its simple, takes the form of a process in repeated layered cycles, has a mentor or instructor, self-reflection and is easy to implement by accommodating 
to the characteristics of teachers, the learning environment, the teaching strategies, the criteria for used to judge children's creativity (Billen, 2015; Bandura, 1982; Cheung, 2012; Higgins, 2004; Kazu, 1996).

\section{Components that need to be added in the Teaching Practice Patterns in Online TSC Course and reasons}

Each subject provides input on the components that must be added and displayed in the teaching practice patterns. Their answers are then listed and grouped according to their similarity. After being analyzed, the components that must be added and displayed in the pattern are as follows; 1 ) Video of the implementation of practices carried out by students. This video is important in the OT pattern because it can prove that students actually teaching practice by being accompanied and assessed by supervisors. This video must be seen, analyzed and commented on by other students in the same class so that it can be given input or reviewed by other students. With this video, students can also reflect on their teaching abilities and can improve them according to the competencies in this course. 2) Online pre and post tutorial activities. This activity needs to be displayed or provided so that students can prepare themselves and the files needed before OT begins and evaluate themselves and complete the files collected after the OT period ends. This pre and post activity can be provided for one week before and one week after the OT period.

\section{Teaching Practice Patterns in Online TSC Course}

Based on the results of data processing, the researchers tried to develop an online tutorial pattern for teaching practice courses (Fig. 2). This pattern accommodates several components that should be present in teaching practice learning. These components include, among others, teaching, planning, implementation of teaching practices, self-reflection from students who practice teaching, peer evaluations and supervisors or supervisors, and evidence of coaching carried out by students and supervisors. In this pattern also illustrated the activities carried out by students in the online tutorial application and outside the online tutorial application. The following is an online tutorial, pattern scheme that researchers developed for remote ECE teacher education programs with open, independent and long distances learning systems. In the pattern of this tutorial, students conduct online tutorial activities, with teaching practices being carried out in a real way in the class where they work witnessed and assessed by the supervisor who is chosen by the student. These supervisors are teachers who are considered senior or have more experience than students, for example the principal. The pattern of online tutorials has no difference with the pattern of face-to-face tutorials, especially in terms of the completeness of the components. in both of these patterns the components, planning, implementation, reflection, and observation are still carried out by students. Especially, a file must be completed by the student, namely the learning plan, reflection sheet, and the results of the assessment of the supervisor. The difference lies only in how to implement and report it. In the online pattern tutorial all practice reports carried out by students are reported in the form of both words and videos. In this way, students can achieve the expected competencies even though the tutorial patterns are different, namely face-to-face tutorials and online tutorials. The pattern is described as follows. 

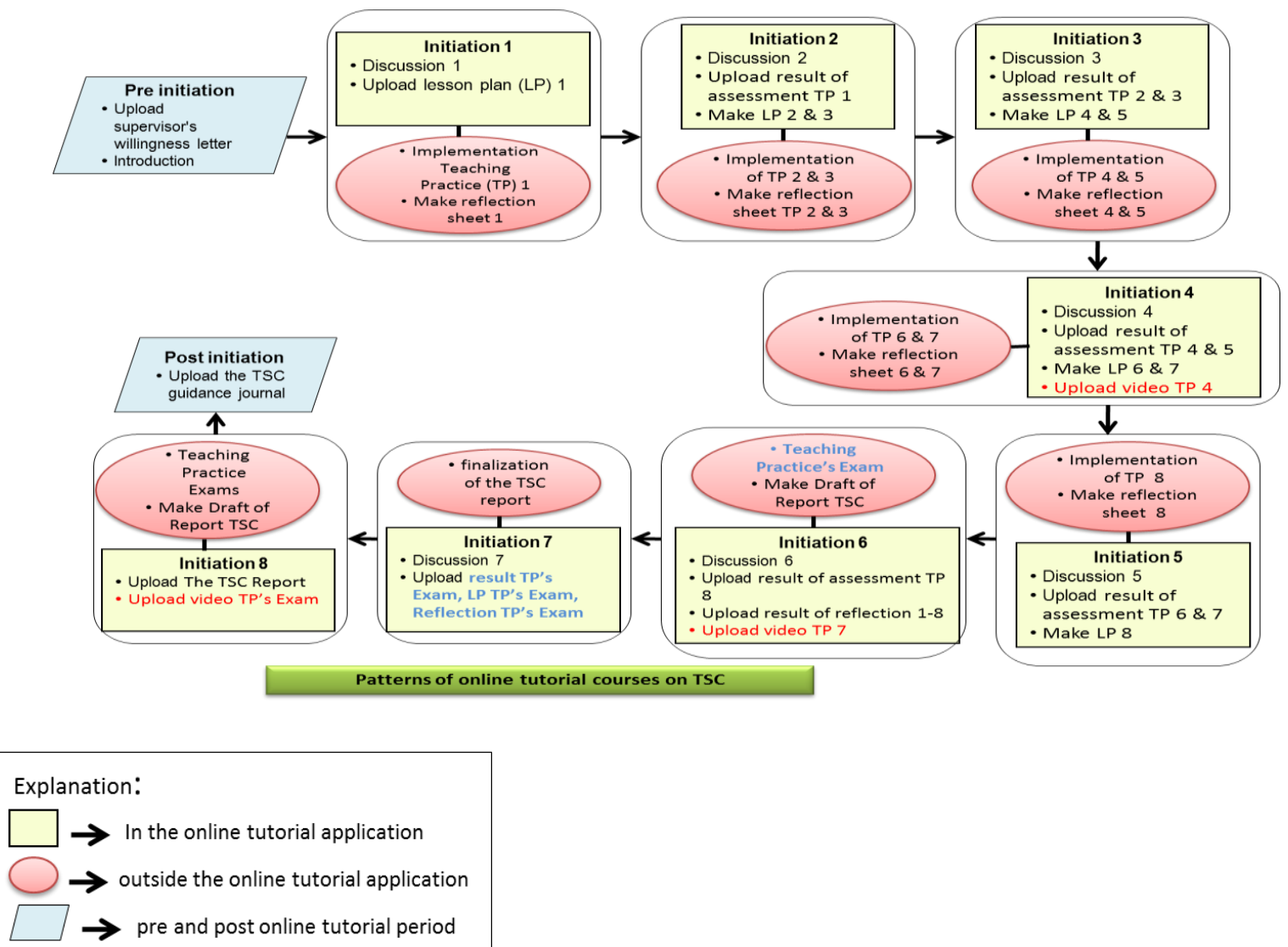

Fig.2 The Teaching Practice Patterns in Online STC Course

The Teaching Practice Patterns (Fig. 2) is clear to compared to the pattern of face-toface tutorials in Fig. 1 This is indeed deliberately done because in online tutorials, no one explained verbally to students. This pattern is deliberately designed so that students can read, understand and apply it independently. In this pattern, students can more easily carry out the teaching practice process because in the pattern the steps and tasks that must be performed by students are drawn. The similarity of pattern in Fig. 1 and 2 is that they last for eight weeks. The obstacle that may be faced in implementing this pattern is when students have to upload their practice report into an online tutorial with the Moodle Application. This obstacle is mainly due to the uneven distribution of the internet network.

\section{CONCLUSION}

The experience of teaching practice for students in teacher education programs is important. In the teaching practice course, students are required to carry out teaching practices as a whole or in micro teaching. Teaching practices should be a cycle ie., planning, implementiation, evaluation and reflection on their own teaching practices. In addition, to evaluate themselves, students can also be evaluated by the others students and peers by online. Therefore, the pattern of learning and coaching should be done in the same ways. This pattern of tutorials that have been developed is an alternative to the implementation of TSC courses that conducted by online. We believe that this pattern can help students to get the good competencies. For future research, we will back with implementation The Teaching Practice Patterns in Online STC Course en massive at the ECE Teacher Education Program.

\section{ACKNOWLEDGMENTS}

I would like to thank University Terbuka especially the Dean of the Teaching and Education Faculty who has provided support and to students who have agreed to be respondents in this study. 


\section{REFERENCES}

Anfas, et.al. (2020). Faktor Motivasi Eksternal Yang Menentukan Prestasi Belajar Mahasiswa. Jurnal Ilmu Sosial dan Pendidikan Vol. 4. No. 2 Maret 2020 DOI: 10.36312/jisip.v4i2.1080 pISSN: 2598-9944 e-ISSN: 2656-6753, 2010-2018.

Bandura, A. (1982). Self-efficacy mechanism in human agency. USA: American Psychologist, 37, 122- 147.

Billen, K. (2015). Effect of micro teaching technique on teacher candidates' beliefs regarding mathematics teaching. Procedia - Social and Behavioral Sciences 174. Procedia - Social and Behavioral Sciences 174 ( 2015 ). DOI: 10.1016/j.sbspro.2015.01.590 , 609 - 616 .

Cheung, R. H. (2012). Teaching for creativity:Examining The Beliefs of Early Childhood Teachers and Their Influence on Teaching Practices. Australasian Journal of Early Childhood Volume 37 Number 3 September 2012. DOI: 10.1177/183693911203700307, 43-52.

Cho, M.H., \& Heron, M. L. (2015). Self-regulated learning: The role of motivation, emotion, and use of learning strategies in students' learning experiences in a self-paced online mathematics course. Distance Education, Vol 36 No.1, . DOI: 10.1080/01587919.2015.1019963, 80-89.

Currie, J. (2020). Early Childhood Education Programs. Journal of Economic Perspective, 15(1), Retrieved MarThe Journal of Economic Perspectives, 15(2), 213-238. Retrieved August 11, 2020, from www.jstor.org/stable/2696599, 213-238.

Dhull and Sakshi. (2017). Online Learning. International Education \& Research Journal [IERJ] Volume : 3 Issue : 8 Aug 2017. E-ISSN No : 2454-9916 |, 32-34.

Diki, D. (2013). International Collaboration of Distance Learning Universities for Online Learning in Indonesia. LUX: A Journal of Transdisciplinary Writing and Research from Claremont Graduate University Vol 2. Iss. 1, Article 12. DOI: 10.5642/lux.201301.12, 1-8.

Fahrman, et. al. (2020). Experienced Technology Teachers' Teaching Practices. International Journal of Technology and Design Education 30. DOI: 10.1007/s10798-019-09494-9, 163-186.

Faour, B. (2003). Early Childhood Teachers in Lebanon: Beliefs and Practices. Lebanon: University of Leicester.

Fatmasari. (2018). Teaching Practice in Distance Education Context. Global Conference on Teaching, Assessment, and Learning in Education (p. 7). Jakarta: SHS Web of Conferences 42,00099 .

FKIP Team. (2017). Panduan pemantapan kemampuan Mengajar. Jakarta: Universitas terbuka.

Gasbarro, M. (2008). Educating the Educators: Effective Practices for Early Childhood Teachers' Training and Professional Development. Denver: University of Denver.

Hal Hill, et.al. (2014). Economic geography of Indonesia: location, connectivity, and resources (Chapter 8). In B. P. Hal Hill, Reshaping Economic Geography in East Asia (2008) (pp. 115134). Jakarta: Australian National University.

Higgins, A. (2004). The experiences of lecturers and students in the use of microteaching as a teaching strategy. Dubllin: Nurse Education in Practice, 3, 220-227.

Istianda, M. (2019). Online Learning dan Hubungannya Dengan Keterampilan Literasi Digital (Studi Kasus Pada Pendidikan Jarak Jauh). Jurnal Sebatik (Sekolah Tinggi Ilmu Komputer) Vol 23 No. 1. DOI: https://doi.org/10.46984/sebatik.v23i1.449. , 91-97.

Kazu, H. (1996). Öğretmen yetiştirmede mikro öğretim yönteminin etkinliği. Turkey: (Firat Üniversitesi Teknik Eğitim Fakültesi Örneği), (Basılmamış Doktora Tezi), Fırat Üniversitesi Sosyal Bilimler Enstitüsü.

Keengwe, J. (2009). Technology and Early Childhood Education: A Technology IntegrationProfessional Development Model for Practicing Teachers. Early Childhood Educ J (2009) 37.DOI 10.1007/s10643-009-0341-0, 209-218.

Kusmawan, U. (2017). Online Microteaching: A Multifaceted Approach to Teacher Professional Development. Journal of Interactive Online Learning (JIOL). Volume 15, Number 1, Summer 2017. ISSN: 1541-4914, 42-56. 
Lewis, C. C. (2002). Lesson study: Ahandbook of teacher led instructional change, . Philadelpia, PA: Research for Better School, Inc.

McMillion, and King. (2017). Communication and Security Issues in Online Education: Student Self-Disclosure in Course Introductions. Journal of Interactive Online Learning Volume 15, Number 1, Summer 2017 ISSN: 1541-4914, 1-25.

Michalopoulou, M. S. (2017). Early Childhood Education Curricula: Human Rights and Citizenship in Early Childhood Education. Journal of Education and Learning; Vol. 6, No. 2. ISSN 1927-5250 E-ISSN 1927-5269. DOI:10.5539/jel.v6n2p53 , 53-68.

Nguyen, J. L. (2017). An Undergraduate Inclusive teacherPreparation Programme In Early Childhood Education:an Online Delivery Approach. Florida: Florida Atlantic University.

Nikolopoulou, K. (2015). ICT and Play in Preschool: Early Childhood Teachers' Beliefs and Confidence. International Journal of Early Years Education 02 Sep 2015. DOI: 10.1080/09669760.2015.1078727, 1-17.

Palomino, M. d. (2016). Teacher training in the use of ICT for inclusion: differences betweenEarly Childhood and Primary Education. 7th International Conference on Intercultural Education "Education, Health and ICT for a Transcultural World", Eduhem 2016, 15-17 June 2016, (pp. 144-149). Almeria, Spain: Procedia - Social and Behavioral Sciences 237 ( 2017 ).

Polovina, S. (2014). On The Practicalities of Distance Learning Using the World Wide Web: Technical Report SBU-CISM-95-21. London: School of Computing, Information System Matematics.

Rohita, e. (2018). Teacher's Understanding of the Scientific Approach in the 2013 Curriculum for Early Childhood Education. Jurnal Obsesi Vol 2 No 2. DOI: 10.31004/obsesi.v2i2.105, 237-246.

Sokolova, et.al. (2018). The Pros and Cons of Distance learning. 18th PCSF 2018 Professional Culture of the Specialist of the Future (pp. 1474-1486). Russia: The European Proceedings of Social \& Behavioural Sciences EpSBS.

Suhartono, D. (2015). Pemodelan Pembimbingan Praktik Pemantapan Kemampuan Profesional (PKP) Pada Mahasiswa Pendidikan Jarak Jauh Melalui Lesson Study. Jurnal Pendidikan Terbuka Dan Jarak Jauh, Volume 16, Nomor 1, Maret 2015,, 10-28.

T. Atay, et.al. (2018). The new Turkish Early Childhood Teacher Education Curriculum: A Brief Outlook. Asia Pacific Educ. Rev. (2009) Vol 10. DOI 10.1007/s12564-009-9034-z, 345-356.

Tatminingsih, S. (2019). Coloured Stick: Teaching with a Comprehensive Game for Improving Children's Social-emotional Ability. Különleges Bánásmód Journal, V.ÉVF. 2019/1., 59-65.

Terbuka, U. (2017). Laporan Rektor Universitas Terbuka. Jakarta: Universitas Terbuka.

Traxler, J. (2018). Distance Learning-Predictions and Possibilities. Education Sciene Journal Ed 8 (1). March.No.35. DOI: 10.3390/educsci8010035, 1-13.

Undiyaundeye. (2018). Micro-Teaching Experiences in a Pre-Service Early Childhood Education Programme Nigeria. Nigeria: Nigeria Federal College of Education, Obudu, Cross River State.

Yildirim, A. (2010). Creativity in Early Childhood Education Program . Procedia Social and Behavioral Sciences 9 (2010). DOI:10.1016/j.sbspro.2010.12.365, 1561-1565.

Zakiya and Nurhafizah. (2019). Pengembangan Keprofesian Berkelanjutan dalam Meningkatkan Profesionalisme Guru Pendidikan Anak Usia Dini. Jurnal Obsesi Vol 3 Issue 2. DOI: 10.31004/obsesi.v3i2.196, 356-365. 